\title{
Geochemistry and Petrogenetic Relationships Between Pegmatites and Host Rocks in the Keffi Area, North Central, Nigeria
}

\author{
I. Y. Tanko and K. Dzigbodi-Adjimah
}

\begin{abstract}
Keffi pegmatites area which contains numerous mineralised and non-mineralised pegmatites lie between the Wamba pegmatite field to the $\mathrm{NE}$ and Nasarawa pegmatite field to the SW on the North Central Pegmatite belt of Nigeria. In Keffi area exploitation of deposits is currently being done by small scale miners, whose activities are haphazard and uncoordinated, because of that information on the geology and petrology that will enable a systematic study of the pegmatites in the area is scanty. Systematic geochemical investigations of the pegmatites and surrounding host rocks aimed at establishing petrogenetic relationships amongst the various rock types in the area were conducted. Major, trace and REE investigations of the pegmatites and associated granitoids have indicated petrogenetic relationships amongst the pegmatites and between the pegmatites and surrounding granitoids of Keffi area. Also, the variation diagram of major, trace and REE in whole rocks and K-feldspar samples show patterns which categorised the pegmatites of Keffi area into; (1) Nonmineralised, (2) intermediate and (3) mineralised pegmatites. It was also deduced from the geochemical characteristics (variation diagrams in major and trace element, REE geochemistry and tectonic environment classification) that a genetic model based on the evolution of melt by partial melting of metasedimentary protolith during ultrametamorphic and deformational activities (anatexis) is proposed for the granitepegmatite system of Keffi area. This information will be useful as guide for fruitful exploration of the pegmatites and serves as model for the exploitation of pegmatite veins in similar geologic settings.
\end{abstract}

Index Terms - geochemistry, granites, Pegmatite, petrogenesis.

\section{INTRODUCTION}

The importance of geochemical studies in resolving problems in pegmatite geology have been demonstrated in several studies, for example [1]-[8]. The chemical composition (major, trace Rare Earth Element (REE) of schists, granodiorites, granites, pegmatites and their mineral feldspars and micas give important information for petrogenesis and favours the evolution of melt by partial melting of metasedimentary protolith [3], [6], [9]-[14].

Keffi pegmatite area is bounded by $8^{\circ} 40^{\prime} 00^{\prime \prime} \mathrm{N}$ and $8^{\circ} 50^{\prime}$ $10^{\prime \prime} \mathrm{N}$ and $7^{\circ} 50^{\prime} 00^{\prime \prime} \mathrm{E}$ and $8^{\circ} 02^{\prime} 00^{\prime \prime} \mathrm{E}$ and cover about $326.25 \mathrm{~km}^{2}$ on a scale of 1:50,000 (see Fig. 1). In Keffi area exploitation of deposits is currently being done by small scale miners, whose activities are haphazard and

Published on February 8, 2021.

I. Y. Tanko, Department of Geology and Mining, Nasarawa State University, Keffi, Nigeria.

(e-mail: iyantanko2014@gmail.com)

K. Dzigbodi-Adjimah, Department of Geological Engineering, University of Mines and Technology, Tarkwa, Ghana. uncoordinated. For example, (i) mineralized veins are not distinguished from unmineralized ones. (ii) Petrogenetic relationships amongst the pegmatites and between the pegmatites and surrounding granitoids of Keffi area that will enable determination of mineral potentials have not been established. (iii) Information on the geology and petrology that will enable a systematic study of the pegmatites in the area is scanty.

This investigation focused on detailed geochemical investigations of the pegmatites to characterize /classify and establish petrogenetic relationships among various rock types in the area. It will also provide guide for fruitful exploration of the pegmatites and serve as model for the exploitation of pegmatite veins in similar geologic settings.

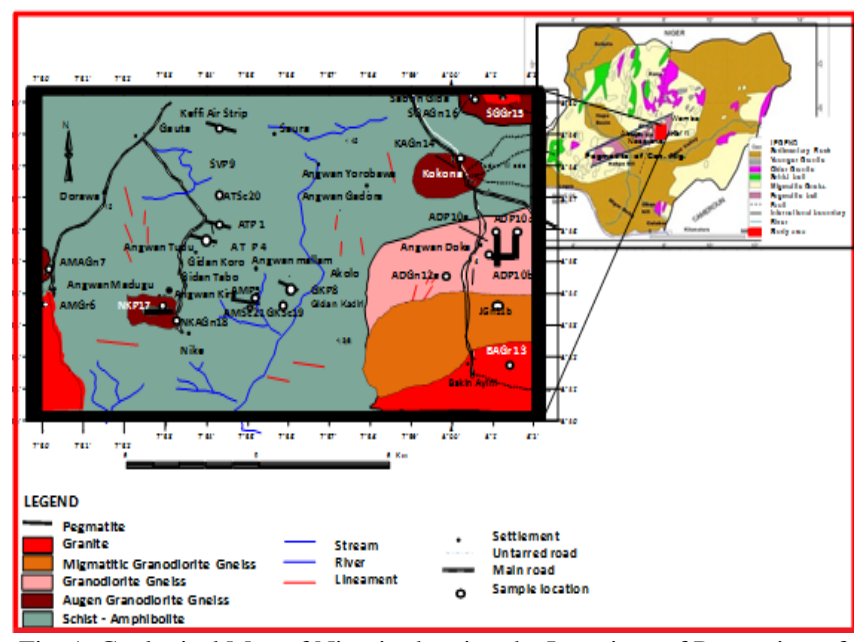

Fig. 1. Geological Map of Nigeria showing the Locations of Pegmatites of Central Nigeria (Modified after [15]) and the Study Area.

\section{Geological Setting}

The Nigerian basement complex forms part of the Pan African mobile belt and lies between the West African and Congo Cratons and south of the Tuareg shield [21], [16], [17] (Fig. 2). The Pan African mobile belt believed to have evolved from the collision between the passive continental margin of the West African craton and the active continental margin of the Tuareg shield about $600 \mathrm{Ma}$ ago [16], [17] experienced deformation, thermal reactivation, metamorphism and emplacement of large volume of granitoids typical of a Himalayan-type orogenesis during the Pan African thermo tectonic event (600 $\pm 150 \mathrm{Ma})$ [22].

The Nigerian Basement rocks have experienced at least four major orogenic cycles of deformation, metamorphism and remobilisation corresponding to the Liberian (2,700 Ma), the Eburnean (2,000 Ma), the Kibaran 
(1,100 Ma) and the Pan African Cycles (600土150 Ma) [18][20]. The first three cycles of deformation are characterized by isoclinal folding accompanied by regional metamorphism and followed by extensive migmatisation, whilst the last cycle was characterized by deformation, metamorphism and granitization. This granitization culminated in the intrusion of a diverse and widespread suite of syn-to late tectonic emplacement of granites and granodiorites and syenites, with associated contact metamorphism accompanying the end stages of the last deformation. The closing stages of the Pan African Orogeny were marked by cooling, uplift, fracturing, and the intrusion of high level volcanic rocks [23], [24].

Within the Basement Complex of Nigeria, four major lithotectonic and geochronological units are distinguishable, namely: Migmatite-Gneiss Complex of Archaean to Proterozoic age, The Schist Belt (Metavolcano sedimentary rocks) of late Proterozoic age, The Older Granites or Pan African Granitoids of Paleozoic age and Undeformed felsic and mafic Dykes of late Paleozoic. This present discussion deals only with the Pan African Granitoids because pegmatites the subject of the present investigation are integral part of the Pan African Granitoids of the Nigerian Basement Complex [1], [15], [25].
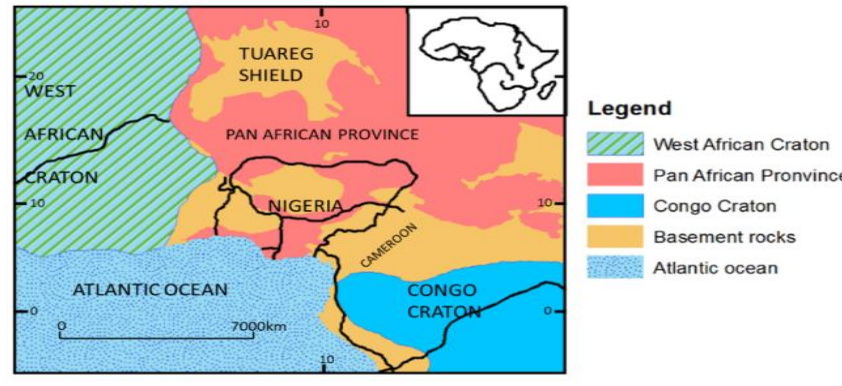
Pan African Pronvince Congo Craton Basement racks

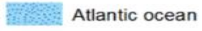

Fig. 2. Location of the Nigeria sector of the Pan-African province of West Africa (modified after [26].

\section{Methods And Materials Used}

The different outcrops investigated include pelitic schistamphibolite, orthogneisses (granodiorite and augen granodiorite gneisses), granites and pegmatites. Their lithology, structure, mineralogy, texture, foliation, homogeneity, outcrop appearance, and general field conditions were identified, measured, and recorded. Generally, outcrops were relatively at high altitudes (about 20-25 m) with gentle to steep cliffs.

\section{A. Sampling, Preparation and Analytical Methods}

Samples were collected from all the identified rock types, at first at about $1 \mathrm{~m}$ interval within the granites and host rocks, but close to contacts and into hosted pegmatite bodies, interval close up at about $0.5 \mathrm{~m}$ and $0.25 \mathrm{~m}$. This is to identify if any relationships exist between pegmatites and surrounding orthogneisses and schist-amphibolite host rocks. Samples of pegmatites were collected in an oriented manner from the hanging wall from the host rock and across the pegmatites into the host rocks on the footwall. Samples were also collected both at the surface and at some depth below the present level of excavation to ensure samples are fresh and representative.
About 150 whole rock and mineral samples were collected, out of which 69 were selected for geochemical analyses. Whole rock samples of pegmatites for geochemical analysis were composited. Composite samples were obtained by mixing and blending all the whole rock samples collected from each zone or location in a pegmatite and ground to powder. The resultant single homogeneous powder form is a composite of the samples collected from that zone or location. Samples are composited because the large grain size of pegmatite makes it difficult to have good proportions of all the minerals in a single rock specimen. This was also the reason why some individual mineral (Kfeldspar) grains were extracted from the same whole rock samples for geochemical analysis.

The treated whole rock and mineral samples (pulp) were digested and analyzed in the ACME laboratory limited, Vancouver, Canada. Major, trace and REE contents for the whole rock samples and K-feldspar separates of the pegmatites were determined using ICP-MS analysis, but some were treated by ICP-ES and specific ion electrode techniques depending on the element of interest.

\section{LOCAL GEOLOGY}

The granitoids which consist of pegmatites, granites and orthogneisses (granodiorites and augen granodiorites) were uncomfortably emplaced in the basement rock units in the area. Distribution of these granitoids is shown in Fig. 1. Grade of metamorphism in the metasedimentary rocks of the area varies from upper greenschist facies to lower amphibolite facies. The main structural features in the area are the penetrative tectonic foliations trending mainly in the N-S, E-W, NE-SW and NW-SE directions, metamorphism, folding, faults, fractures, and joints mostly believed to have been reactivated or formed during the Pan African tectonic events $(600 \pm 150 \mathrm{Ma})$ [22].

\section{GEOCHEMISTRY}

Geochemical investigations were carried out on some selected samples to determine major, trace and Rare Earth Element (REE) variations within the various rock types and between one rock type and another. This is to understand the evolution (i.e., relationships with the surrounding rocks) of the pegmatites, and tectonic environments classification of the pegmatites and associated granitoids in Keffi area whose most mineralogical characteristics were obliterated and could not be resolved under the microscope.

\section{A. Major and Trace Element Contents of Whole Rock} Samples of Pegmatites, Granites and Host Rocks

This section analyses and interprets the results of the geochemical investigation of the pegmatites, granites, and other host rocks in the area. The range of major and trace element contents of whole rock (composite) samples of the pegmatites of Keffi area are presented as follows. The major element contents range: $\mathrm{SiO}_{2}$ 64.00-73.57\%, $\mathrm{Al}_{2} \mathrm{O}_{3}$ 16.04.01-21.80\%, $\mathrm{Fe}_{2} \mathrm{O}_{3}$ 1.02-3.87\%, $\mathrm{MgO} 0.02-0.58 \%$, $\mathrm{CaO} 0.10-3.03 \%, \mathrm{Na}_{2} \mathrm{O}$ 0.49-7.50\%, $\mathrm{K}_{2} \mathrm{O} 2.75-6.71 \%, \mathrm{TiO}_{2}$ $0.01-0.19 \%, \mathrm{P}_{2} \mathrm{O}_{5}$ 0.07-1.70\%, MnO 0.06-0.42\% and $\mathrm{Cr}_{2} \mathrm{O}_{3}$ $0.002-0.013 \%$. Whilst the trace elements range as $\mathrm{Rb}$ 
100.10-2 500.21 ppm, Cs 68.40-2 100.00ppm, Li 200.006400.00 ppm, F 680.00-10 000.00 ppm, Sr 8.70133.20 ppm, Ba 27.00-246.00 ppm, Y 0.30-9.10 ppm, Zr 6.80-342.20 ppm, K/Rb 0.001-0.010. Below are variation diagrams (see Fig. 3(a) and (b) and 4(a) and (b) showing trends in major and trace element contents of whole rock samples of pegmatites in Keffi area.

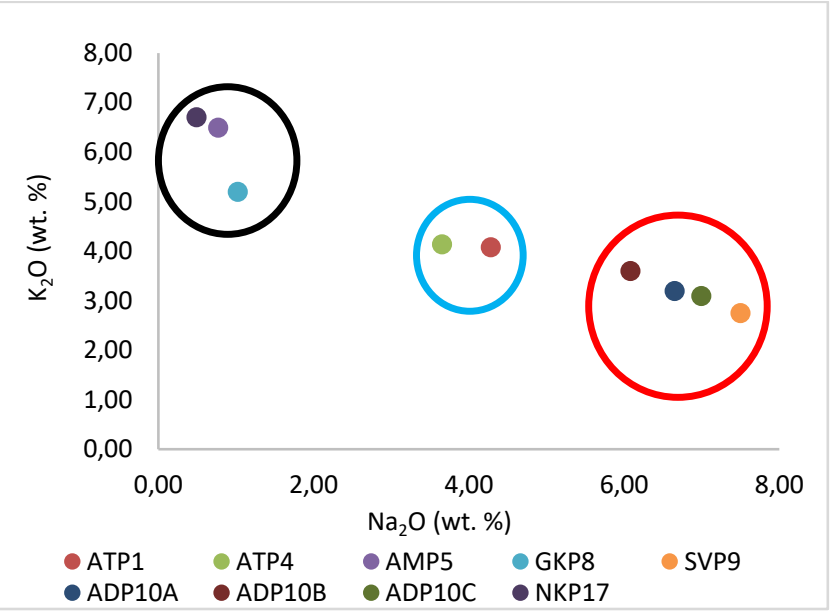

(a)

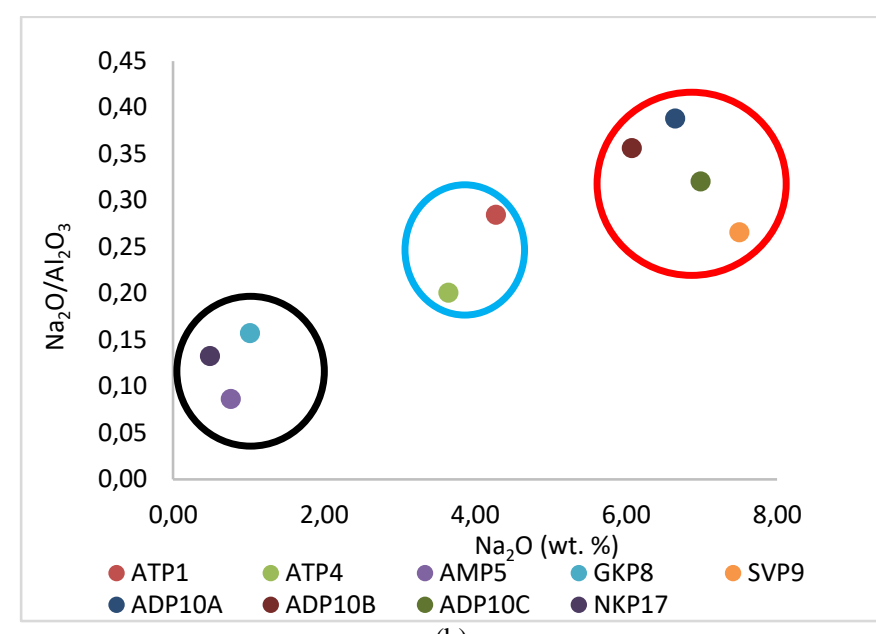

(b)

Fig. 3. (a) and (b). Plots of Variations for Major Element Contents in Whole Rock Samples from Pegmatites of Keffi Area.

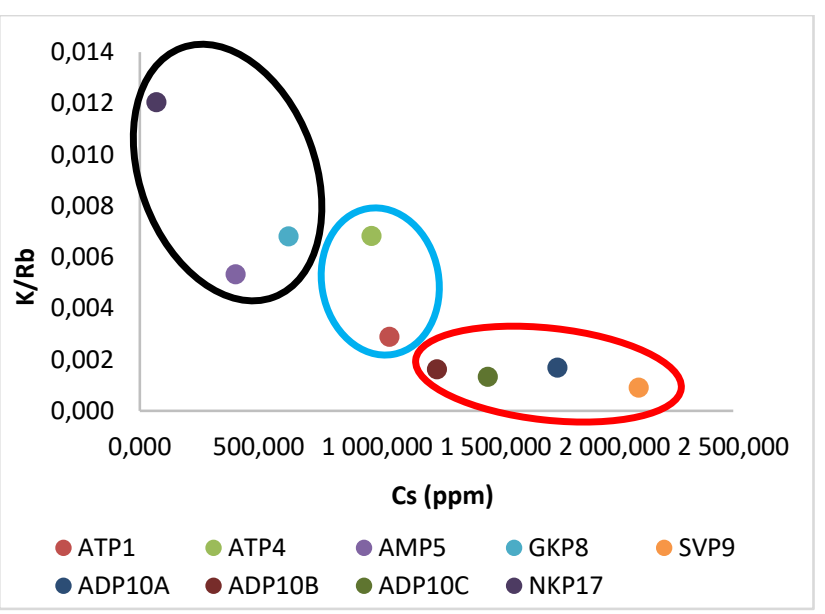

(a)

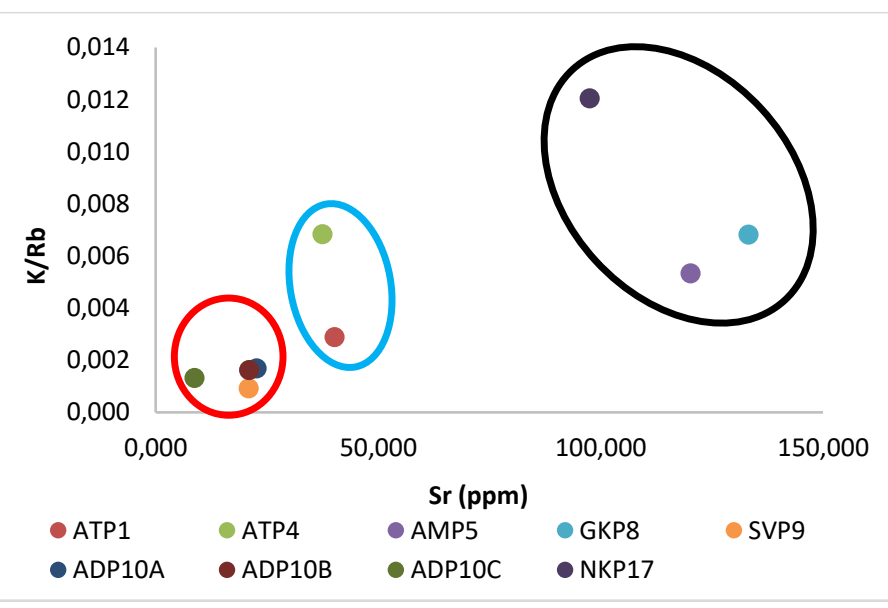

(b)

Fig. 4. (a) and (b). Plots of Variations in Trace Element Contents of Whole Rock Samples from Pegmatites of Keffi Area.

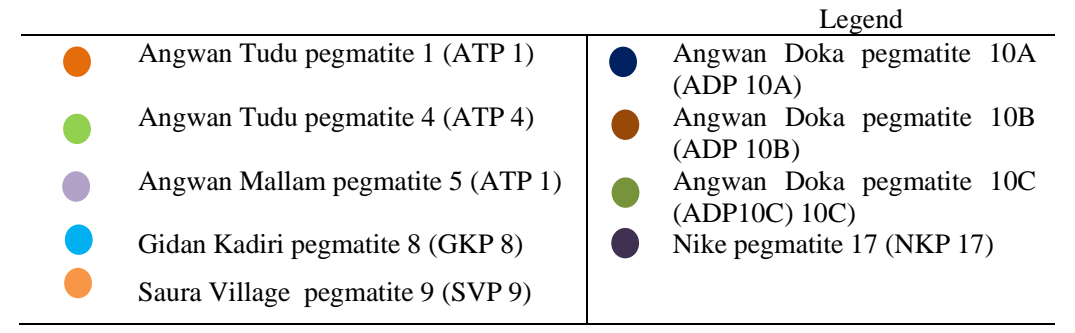

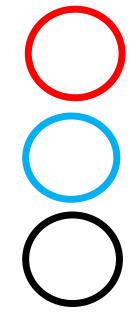

Mineralized Pegmatites

Intermediate Pegmatites

Non-mineralized Pegmatites

\section{B. Major and Trace Element Contents of K-feldspar Samples of Pegmatites}

Ranges of major and trace element contents of K-feldspar samples from pegmatites are presented below and variations of these elements in K-feldspar are shown in Fig. 5 (a) and (b) and 6 (a) and (b). Ranges of major elements contents in $\mathrm{K}$-feldspar samples of the pegmatites of Keffi area are as follows; $\mathrm{SiO}_{2}$ 61.08-67.08\%, $\mathrm{Al}_{2} \mathrm{O}_{3}$ 18.17-19.91\%, $\mathrm{Fe}_{2} \mathrm{O}_{3}$ $0.19-0.98 \%, \mathrm{MgO} 0.01-0.32 \%, \mathrm{CaO} 0.03-2.37 \%, \mathrm{Na}_{2} \mathrm{O}$ $0.38-10.18 \%, \quad \mathrm{~K}_{2} \mathrm{O} \quad 0.78-15.76 \%, \quad \mathrm{TiO}_{2} 0.01-0.13 \%$, $\mathrm{P}_{2} \mathrm{O}_{5} 0.04-0.83 \%, \quad \mathrm{MnO} 0.01-0.48 \%$ and $\mathrm{Cr}_{2} \mathrm{O}_{5}$ 0.002$0.004 \%$. Whilst the trace element ranges as follows: $\mathrm{Rb}$ 52.00-6 918.70ppm, Cs 18.80-2 102.10ppm, Li 100.00-1 100.00ppm, F 31.00-2 701.00ppm, Sn 1.00-659.00 ppm, Nb 0.60-62.40 ppm, Ta 0.30-112.00 ppm, B 4.00-561.00 ppm, Sr 9.40-94.10ppm, Ba 14.00-268.00ppm, Y 0.05-5.80ppm, Zr 0.90-40.00ppm, K/Rb 0.0002-0.1964.

On one hand, $\mathrm{Fe}_{2} \mathrm{O}_{3}, \mathrm{MgO}$ and $\mathrm{CaO}$, and $\mathrm{Al}_{2} \mathrm{O}_{3}$ and $\mathrm{Na}_{2} \mathrm{O}$ contents show steady decrease and corresponding increase respectively throughout the pegmatites in the area, from pegmatite bodies close to granite intrusions to the farthest. Also, the variation diagrams for major elements shown in Fig. 3(a) and (b), and 5 (a) and (b)) of whole rock and Kfeldspar samples respectively. But $\mathrm{K}_{2} \mathrm{O}$ content which would ordinarily appreciate in similar way as exhibited by $\mathrm{Al}_{2} \mathrm{O}_{3}$ and $\mathrm{Na}_{2} \mathrm{O}$ contents, rather decreases. This is probably due to the pervasive alteration of $\mathrm{K}$-feldspars to form more 
albite (albitization). This was also indicated by petrographic investigations as a result of the prevalence of cleavelandite formed during the secondary metasomatic alterations [27].

On the other hand, similar patterns of steady decrease and corresponding increase in trace elements contents of $\mathrm{Rb}, \mathrm{Cs}$, $\mathrm{Li}$ and $\mathrm{F}$, and $\mathrm{Sr}, \mathrm{Ba}, \mathrm{Y}$ and $\mathrm{Zr}$ respectively were observed. The variation diagrams for trace elements shown in Fig. 4 (a) and (b), and 6 (a) and (b)) also show decrease and corresponding increase of $\mathrm{Rb}, \mathrm{Cs}, \mathrm{Li}$ and $\mathrm{F}$, and $\mathrm{Sr}, \mathrm{Ba}, \mathrm{Y}$ and $\mathrm{Zr}$ respectively. The trends also show clustering and overlapping of samples suggesting the effects of late metasomatic alteration by hydrothermal fluids.

On the whole, these observed patterns in the distribution of both major and trace element contents seem to have grouped pegmatites of Keffi area into three as follows; group I (Nike Pegmatite 17 (NKP17), Gidan Kadiri Pegmatite 8 (GKP8) and Angwan Malam Pegmatite 5 (AMP5)); group II (Angwan Tudu Pegmatite 1 (ATP1) and Angwan Tudu Pegmatite 4 (ATP4)) and group III (Angwan Doka Pegmatite10A (ADP10A), Angwan Doka Pegmatite10B (ADP10B), Angwan Doka Pegmatite10C (ADP10C) and Saura Village Pegmatite 9 (SVP9)). The element contents varied among pegmatites, but on the average the categorization remain relatively constant throughout the pegmatites of the area. This probably reflects the stages in evolution of pegmatites from least to highly evolved pegmatites, and it as well represents continuous differentiation/fractionation of the pegmatites.

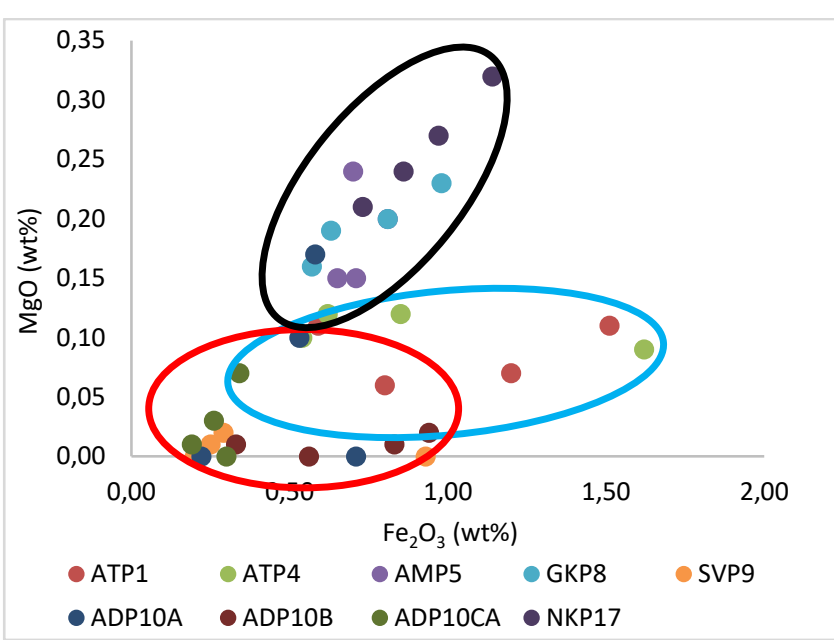

(a)

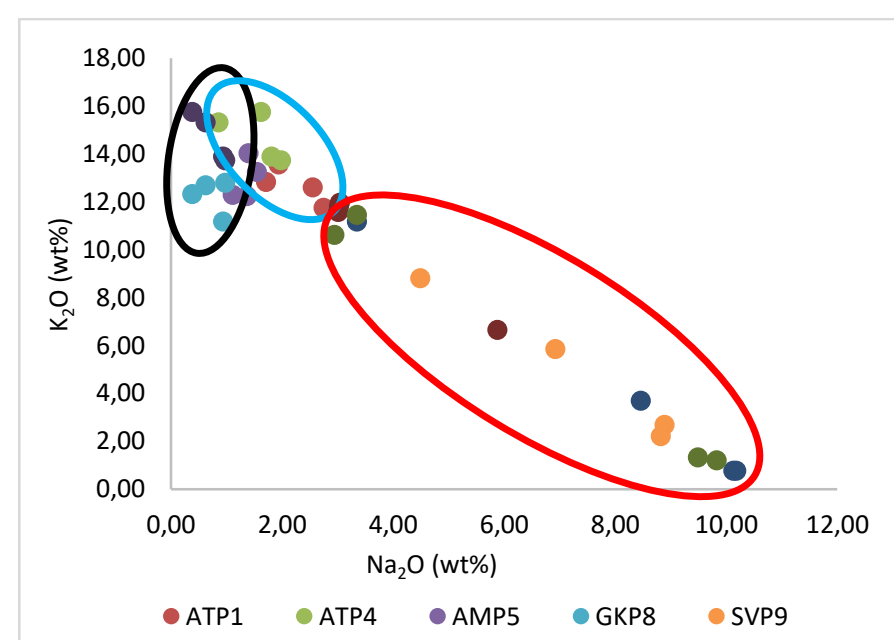

(b)

Fig. 5. (a) and (b). Plots of Variations in Major Element Contents of K-feldspar Samples from Pegmatites of Keffi Area.

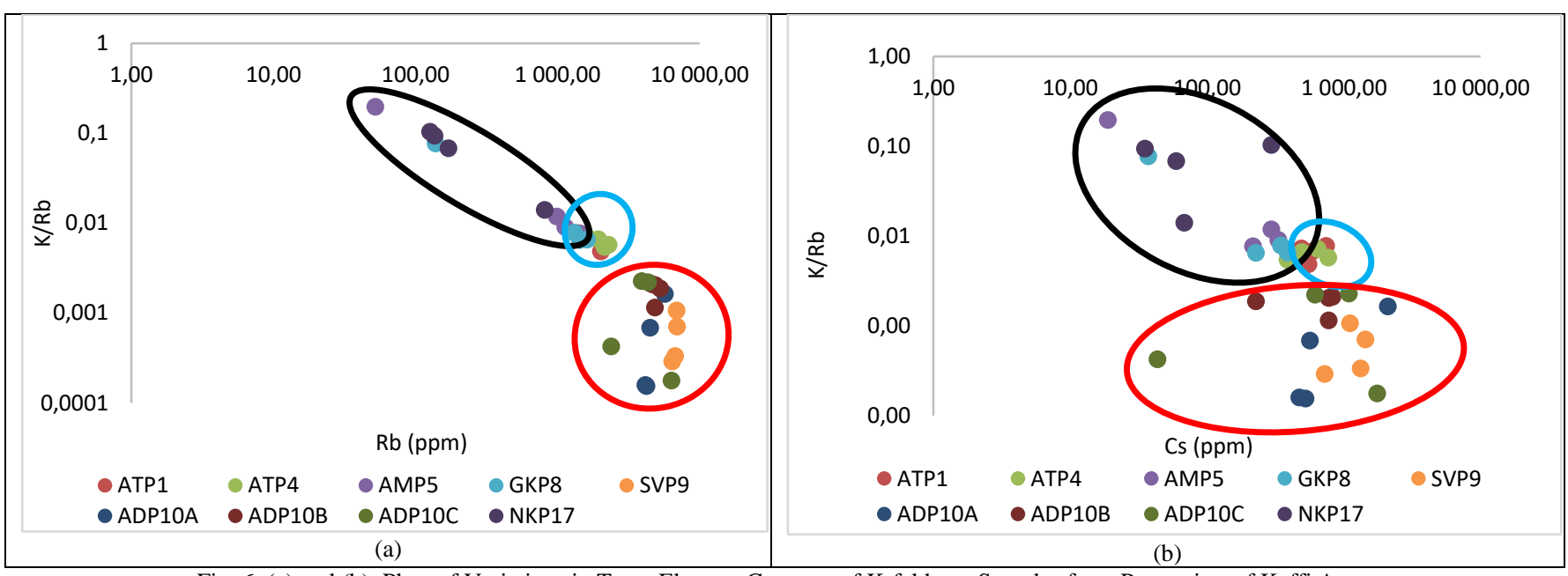

Fig. 6. (a) and (b). Plots of Variations in Trace Element Contents of K-feldspar Samples from Pegmatites of Keffi Area.

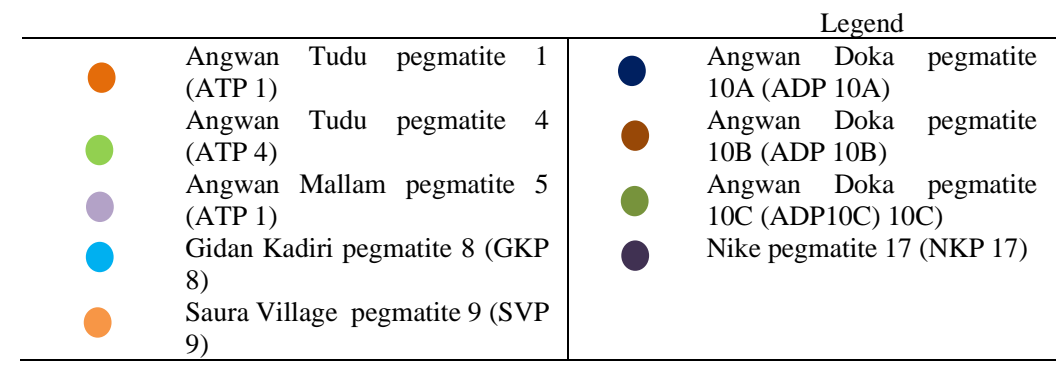

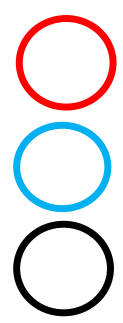

Mineralized Pegmatites

Intermediate Pegmatites

Non-mineralized Pegmatites 


\section{Rare Earth Elements (REEs) Geochemistry}

Chondrite normalized REE patterns in whole rock and $\mathrm{K}$ feldspar samples of pegmatites, and surrounding host rocks are shown in Fig. 7 (a), 7 (b) and 7 (c) respectively.

From Fig. 7(a), 7(b) and 7 (c) it appears the three plots show similar REE characteristics. The REE characteristics of the pegmatite bodies and those of the granitic host rocks show enrichment in Light Rare Earth Elements (LREEs) i.e., La, Ce, Pr and Nd and depletion in Heavy Rare Earth
Elements (HREEs) Ho, Er, Tm, Yb and Lu. They also show sub horizontal patterns. But the horizontal pattern in K-feldspar samples of pegmatites (see Fig. 7(b)) shows more closely spaced pattern than those of the whole rock samples of the pegmatites (see Fig. 7(a)) and the combined pegmatites, granites, orthogneisses and pelitic schistamphibolites (see Fig. 7(c)). Also, the samples from Kfeldspar display very high negative $\mathrm{Eu}$ values and anomalies.

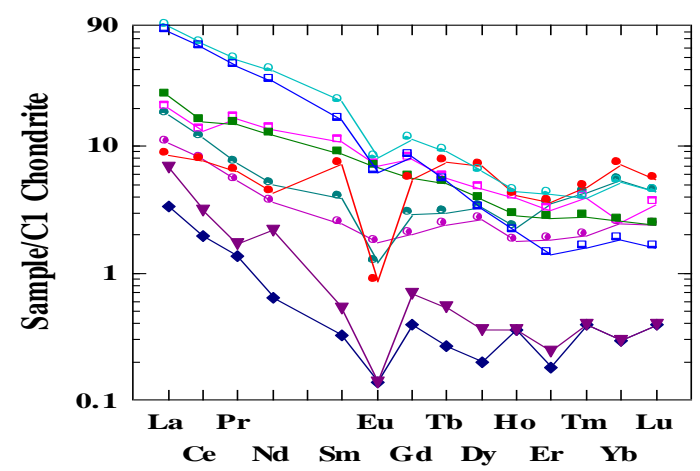

(a)

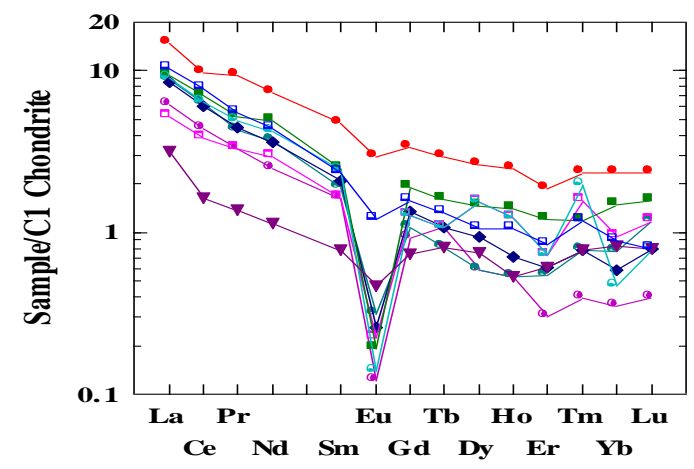

(c)

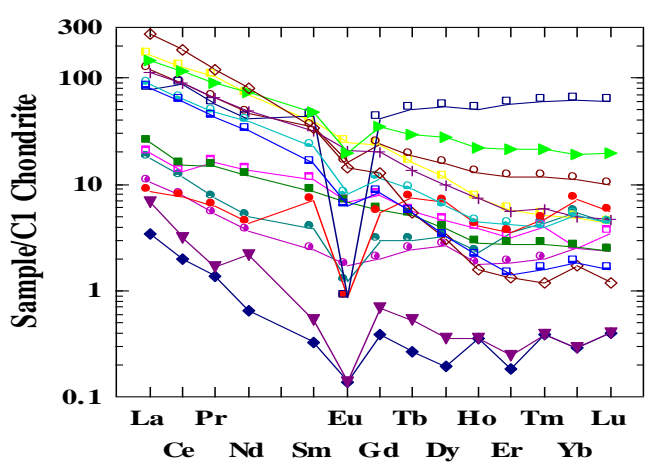

(b)

egend

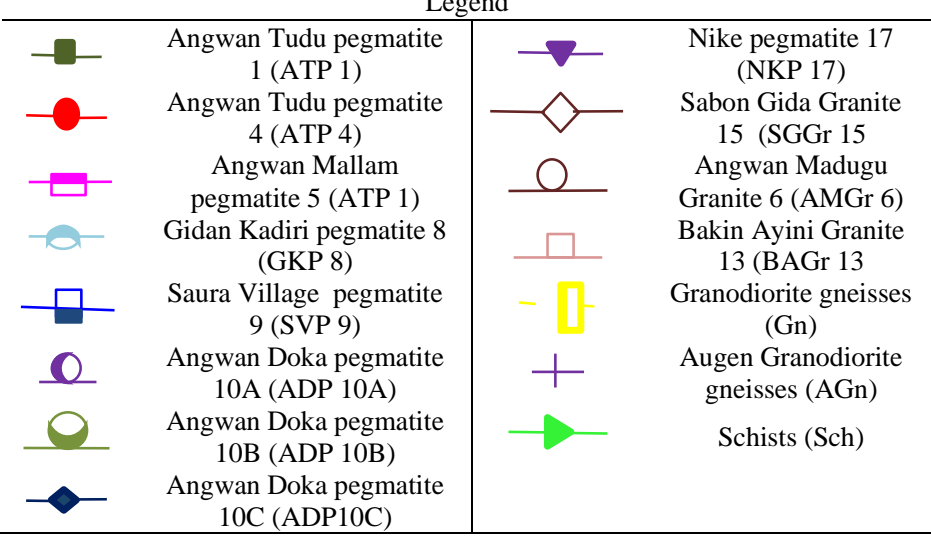

Fig. 7. (a), (b) and (c). Rare Earth Element (REE) Plots in (a) Whole Rock Samples of Pegmatites (b) K-feldsapr samples of pegmatites, and (C) combined REE in pegmatites, Granites, Gneisses and Pelitic schist-amphiboltes from Keffi Area.

D. Major and Trace Element Variations in Whole Rock of Pegmatites, Granites and Host Rocks

To further find out whether or not genetic relationships exist amongst the variousn rock units in the area variation diagrams of major and trace elements of whole rock samples of the pegmatites, granites, granodiorite gneisses, augen gneisses and pelitic-schist- amphibolites were plotted.

\section{DISCUSSION}

\section{A. Petrogenetic Relationships Between Pegmatite and} the Surrounding Host Rocks

From the ranges and variations of the major and trace element contents of whole rock samples, it can be seen that they show continuous trends in all the cases, suggesting continuity in transition. However, in Fig. 8(a) and 8 (b) a marked discontinuity in all the trends between the Bakin Ayini biotite granite (BAGr 13) and the orthogneisses
(Granodiorite gneisses, Gn) is observed, this possibly suggests them belonging to the Older Granite rock series associated with the syn- to late-Pan African magmatic activities as proposed by [5] and [28]. These marked discontinuities clearly show the difference between the Older Granite series and the late to post granitic series associated with the pegmatite's evolution in the area.

The observed similarities in sub-horizontal patterns in the REEs in all the granitic rocks and the surrounding pelitic schist-amphibolites in the area (see Fig. 7(a), 7(b) and 7 (c) show steady decrease in concentration from pelitic schistamphibolites through granodiorite gneisses to granites and lastly to the most fractionated pegmatites. This may be as a result of the roles played by accessory minerals (sphene, garnet apatite, and zircon) and feldspars in the system. Sphene has the capability of accommodating LREE. Whilst garnet, apatite and feldspars can readily accommodate HREE. 
The REE in all the rock units in the area exhibits high LREE values and lower HREE values with all showing progressive increase in negative Eu anomalies. The negative Eu anomalies for most of the granites and pegmatites show somewhat higher anomalies than those of the host rocks (orthogneisses and pelitic schist-amphibolite). This is probably because of the generally low abundance of feldspars, apatite and sphene in granites and pegmatites which reduces the effects of their large partition coefficient. All these observed characteristics of REEs and the overlapping in trace element variations within pegmatites and between pegmatites and other associated rocks implies that the various rock units in the area are co-genetic and thereby suggesting inheritance from the host pelitic schistamphibolites (metasedimentary source protolith).

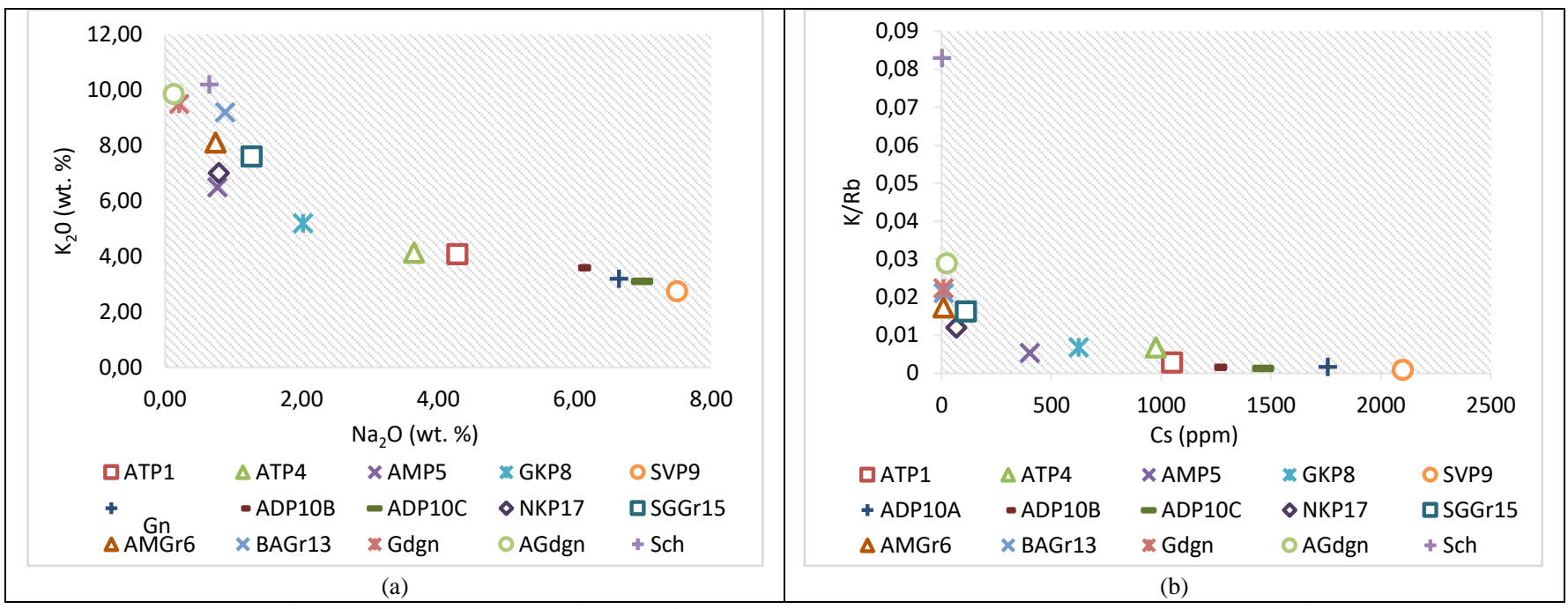

Fig. 8. (a) and (b). Relationships between the Pegmatites, Granites and the Host Rocks (a) Variation in Major and (b) Variation in Trace Elements of Whole Rock Samples.

\begin{tabular}{|c|c|c|c|}
\hline \multicolumn{4}{|c|}{ Legend } \\
\hline [ & Angwan Tudu pegmatite 1 (ATP 1) & $\diamond$ & Nike pegmatite 17 (NKP 17) \\
\hline$\Delta$ & Angwan Tudu pegmatite 4 (ATP 4) & $\square$ & Sabon Gida Granite 15 (SGGr 15 \\
\hline$x$ & Angwan Mallam pegmatite 5 (ATP 1) & $\Delta$ & Angwan Madugu Granite 6 (AMGr 6) \\
\hline 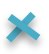 & Gidan Kadiri pegmatite 8 (GKP 8) & $x$ & Bakin Ayini Granite 13 (BAGr 13 \\
\hline - & Saura Village pegmatite 9 (SVP 9) & $x$ & Granodiorite gneisses (Gn) \\
\hline & Angwan Doka pegmatite 10A (ADP 10A) & 0 & Augen Granodiorite gneisses (AGn) \\
\hline- & Angwan Doka pegmatite 10B (ADP 10B) & 4 & Schists (Sch) \\
\hline 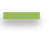 & Angwan Doka pegmatite 10C (ADP10C) & & \\
\hline
\end{tabular}

\section{B. Tectonic Environments Classification of Pegmatites and Associated Granitoids of Keffi Area}

Several works have shown that genesis of most granitic rocks relate to different environments [29]-[31] and different mineralization is also related to different environments, therefore understanding the relationships (affiliation) between granitic rocks and their environments will be key for understanding processes associated with mineralization of pegmatites. Keffi granitoids occurred in faulted or shear fissures environment [27], thus it becomes possible to classify them according to tectonic environment classification scheme. To achieve this target, discrimination diagrams of [32]-[34] were used to discriminate amongst various rock types in the area.

In Fig. 9, majority of the samples fall within rhyoliteclass, whilst GKP8 and AMP5 fall in dacite class, but ATP4 and NKP17 plot along boundary. Three samples (ADP10C, AGn and Sch) also plot in trachyte class. Also, from the plot of $\log \mathrm{Nb}$ vs Log Y shows that majority of the samples fall in the Volcanic Arc Granite (VAG) and Syn-Collisional Granite (SYN-COLG) fields, but some samples also fall in Within Plate Granite (WPG) field. All these are indications of granitic and tectonic nature of the origin of both pegmatites and associated granitic rocks in the Keffi area.

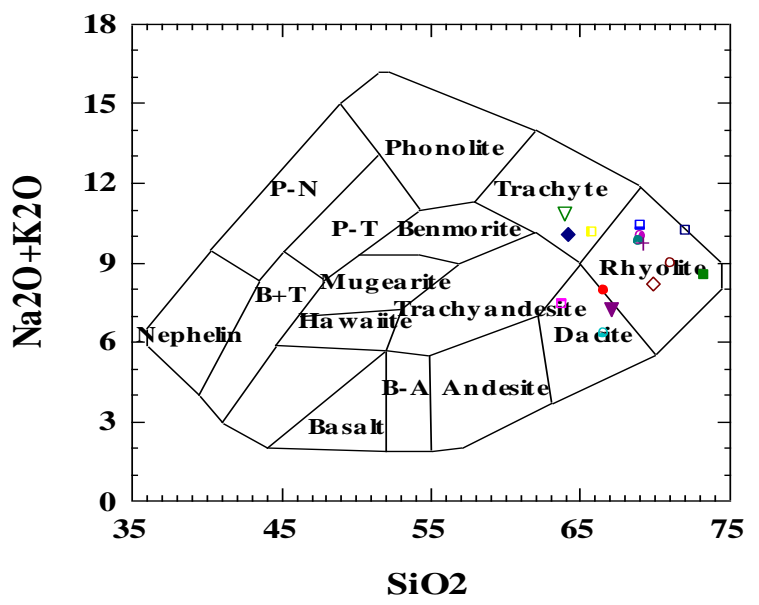

Fig. 9. Plot of $\mathrm{Na}_{2} \mathrm{O}+\mathrm{K}_{2} \mathrm{O}$ vs $\mathrm{SiO}_{2}$ (After [32])/ 


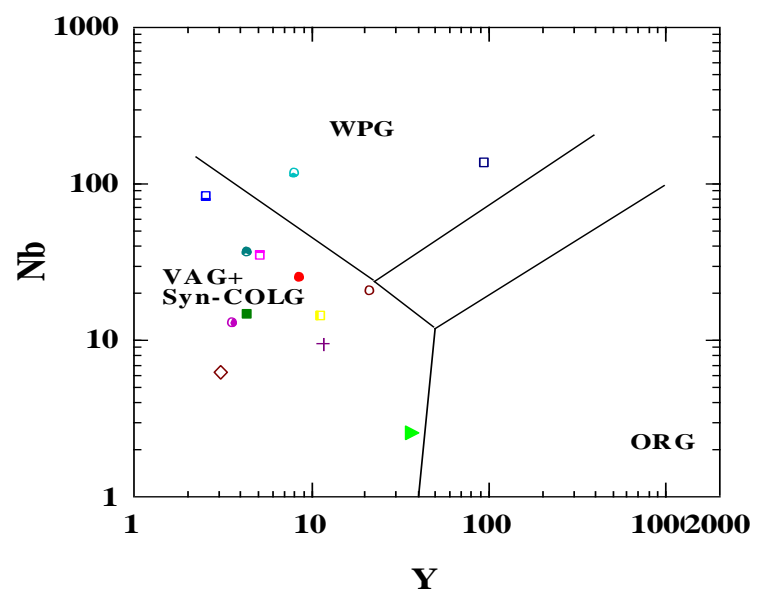

Fig. 10. Plot of Log Nb vs LogY 9 (After [33]).

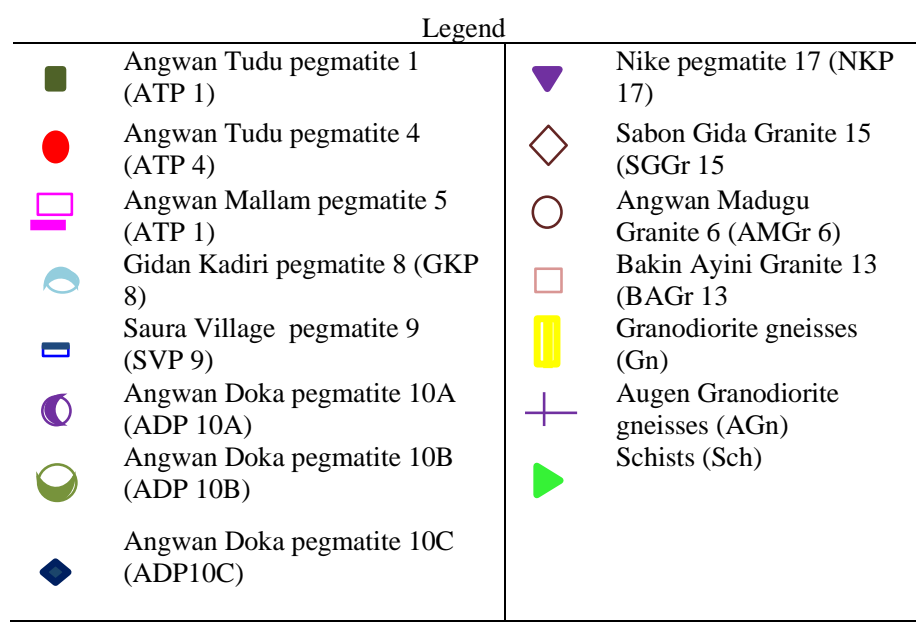

\section{Genetic Model}

On the basis of the outlined evidences discussed above, starting from the major, trace and REE variations diagrams, relationships amongst the various rock types in the area and tectonic environments, it can be concluded that, the melt derived for the formation of the granite-pegmatite system of Keffi area evolved by partial metling of metasedimentary protolith (i.e. the pelitic schist-amphibolites) during ultrametamorphism and deformational processes (anatectic), which probably could be related to the waning stages of the collision-type Pan African thermo-tectonic event [28], [5]. This was immediately followed by an intermediate episode of crystal fractionation to form the biotite granites (the Bakin Ayini granite) and further accumulation and fractionation of the granitic melt forms the more evolved biotite-muscovite granite of Angwan Madugu (AMGr 6). With further concentration and fractionation, the resulting pegmatitic melt, rich in hydrous silicate crystallized to form the Group I (the non mineralized pegmatite) and subsequent accumulation and fractionation continued to form Group II (the intermediate pegmatite) and lastly the extreme fractionation resulted in yielding residual fluids highly enriched in rare element and fluxes to form the most evolved Group III (the mineralized pegmatites). Following this sequence of events, a genetic model below has been proposed for the formation of pegmatites in Keffi area (see Fig. 11).

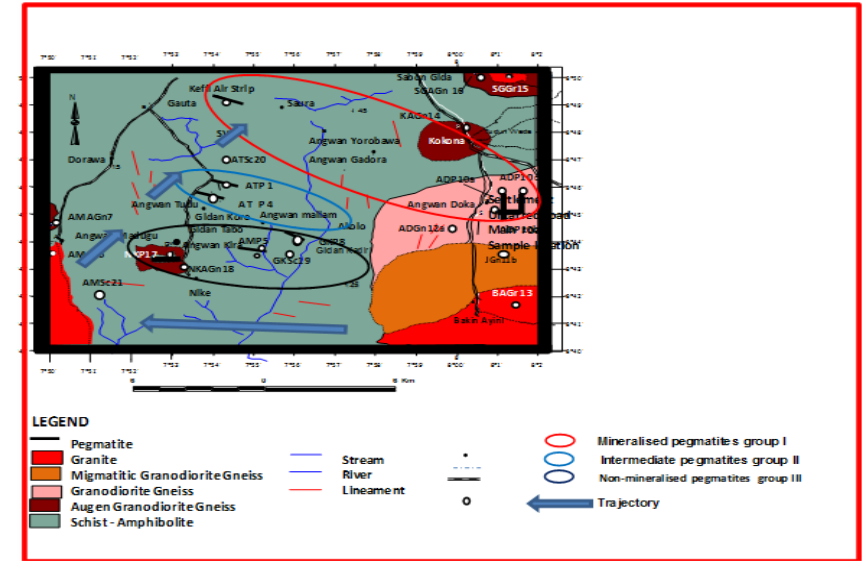

Fig. 11. Genetic Model of the Evolution of Keffi Pegmatites and Granites. It also represents grouping of the Pegmatites.

\section{CONCLUSION}

In the light of the above discussions the following conclusions can be made:

1. The trends in variation diagrams of major and trace elements, and the similarities in REE patterns in whole rock and K-feldspar samples suggest a common metasedimentary source protolith for pegmatites and surrounding granitoids.

2. It also indicates differentiation and fractionation processes of normal granite in situ up to the most evolved rare element pegmatites distal to the probable parent plutons. Thus, establishing the genetic relationships amongst the pegmatites and between the pegmatites and granites and surrounding host rocks in the area.

3. Also, the variation diagrams of major, trace and REE in whole rocks and K-feldspar samples show similar patterns which categorized the pegmatites of Keffi area into; (1) Non-mineralized, (2) intermediate and (3) mineralized pegmatites.

4. Tectonic classification suggests that the pegmatites and granites of Keffi area have affiliation to orogenic and compressional tectonic environments (anatexis).

5. It can be deduced from the outlined evidences discussed above that the melt derived for the formation of the granite-pegmatite system of Keffi area may have evolved by partial metling of the pelitic schist-amphibolites during the regional ultrametamorphic and deformational activities (anatectic), followed by an intermediate episode of crystal fractionation to form the granites (the biotite and biotite-muscovite) and subsequent fractionation continued to form the non-mineralized to intermediate up to mineralized pegmatites. This series of events suggest a genetic model for the formation of the pegmatites of Keffi area.

6. In geochemical investigation the high concentration of $\mathrm{Rb}, \mathrm{Cs}$, Ta vs $\mathrm{K} / \mathrm{Cs}, \mathrm{K} / \mathrm{Rb}$ vs $\mathrm{Cs}$ and the low concentration of $\mathrm{Ba}$ and $\mathrm{Sr}$ are good indicators/criteria for the search of economic mineral potential mineralization in the Keffi pegmatites area. This can also be used in any similar geologic terrain. 


\section{ACKNOWLEDGEMENT}

The authors thank the Tertiary Education Trust Fund Nigeria and Nasarawa State University Keffi, Nasarawa State Nigeria who sponsored this research work. We wish to also express our appreciation to the Geological Engineering Department, University of Mines and Technology, Tarkwa Ghana for the use of their laboratory for sample preparation.

\section{REFERENCE}

[1] R. Jacobson, and J. S. Webb, "The Pegmatite of Central Nigeria", Geological Survey of Nigeria Bulletin, Vol. 17, 61pp. 1946.

[2] A. I. Ginsburg, I. N. Timofeyev, and L. G. Feldman, Principles of Geology of the Granitic Pegmatites, Nedra, Moscow, Russia, pp296. 1979.

[3] P. Cerny "Petrogenesis of Granitic Pegmatites, In Mineralogical Association of Canada, Short Course Handbook, No Granitic Pegmatite in Science and Industry, pp. 405-461., 1982a.

[4] G. B Morgan VI,. and D. London, "Alteration of Amphibolitic Wall rocks Around the Tanco Rare-Element Pegmatite", Bernic Lake Manitoba, Am. Mineral., Vol. 72, pp. 1097-1121. 1987,

[5] D. Kuster, "Rare-Metal Pegmatites of Wamba, Central Nigeria-their Formation in Relationship to Late Pan-African Granites", Mineral Deposita, Vol. 25, pp. 25-33. 1990.

[6] P. Cerny "Rare-Element Granitic Pegmatites, Part I: Anatomy and Internal Evolution of Pegmatite Deposits", Geoscience Can., Vol. 18, pp. 49-67. 1991a.

[7] D. London, "The Application of Experimental Petrology to the Genesis and Crystallisation of Granitic Pegmatites", Can. Mineral, Vol. 30, pp. 499-540. 1992.

[8] P. Cerny., T. S. Ercit, and P. T. Vanstone "Petrology and Mineralisation of the Tanco Rare-Element Pegmatite, Souheastern Manitoba-Field Trip Guidebook A4, Geol. Ass. Can. Annual Meeting, Winnipeg Manitoba, 1996, 63pp.

[9] A. A. Beus "Distribution of Tantalum and Niobium in Muscovites of Granitic Pegmatites" Geokhimiya, No.10. pp. 1216-1220. 1966.

[10] O. D., Staurove, S. Stolyarov, and E. I. Isochewa, "Geochemistry Origin of Verkh Iset Granitoid Massif in Central Ural", Geochem. Intern. Vol. 6, pp. 1138-1146. 1969.

[11] V. V. Gordiyenko "Concentration of $\mathrm{Li}, \mathrm{Rb}$ and $\mathrm{Cs}$ in Potash Feldspar and Muscovites as Criteria for Assessing the Rare Metal Mineralisation in Granite Pegmatites", Internal Geol. Review, No. 13, pp. 134-142, 1971.

[12] J. J. Norton, J. A. Redden, "Relations of Zonned Pegmatites to Other Pegmatites, Granites and Metamorphic Rocks in the Southern Black Hills", South Dakota, American Mineralogist, Vol. 75, pp. 631-655. 1990.

[13] C. K., Shearer, J. J., Papike, B. L. Jolliff, "Petrogenetic Links among Granites and Pegmatites", In the Harney Peak Rare-Element Granite-Pegmatite System, Black Hills, South Dakota, Can. Mineral., Vol. 30, pp. 785-809. 1992.

[14] A. M. R. Neiva, and J. M. F. Ramos, "Geochemistry of Granitic Aplite Pegmatite Sills and Petrogenetic Links with Granites, Guarda-Belmonte Area", Central Portugal, pp. 837-854. 2010.

[15] J. A. Kinnaird, "Contrasting Styles of Sn-Nb-Ta-Zn Mineralisation in Nigeria”, J. Afr Earth. Sci., Vol. 2, No. 2, pp. 81 - 90.1984.

[16] K. C. Burke and J. F. Dewey, "Orogeny in Africa.” In: Dessauvagie, T.F.J. and Whiteman, A. J. (Eds.), African Geology, University of Ibadan Press, Ibadan, pp. 583 - 608, (1972).

[17] R. Caby, J. M. L Brand, and R. Black, "Pan-African Ocean Closure and continental Collision in the Hoggar Iforas Segmen Central Sahara", in Precambrian Tectonics", Edited by a Kroner, Elsevier Amsterdam, pp 407 - 434. 1981.

[18] P. Mc Curry "The Geology of the Precambrian to Lower Paleozoic Rocks of Northern Nigeria- A Review", Geology of Nig, Elizabethan Publ. Co., Lagos,1976, pp.15-40.

[19] M. A. Rahaman, "Review of Basement Geology of Southern Nigeria, In Kogbe”, C. A. (Eds.), Geol. Nigeria Elizabethan, Lagos, Nigeria, 1976, pp. 41-58.

[20] J. B. Wright, "Fracture Systems in Nigeria and Initiation of Fracture Zones in the South Atlantic", Tectonophysics, Vol. 34, pp. 743- 747. 1976.

[21] R. Black, "Precambrian of West Africa", Episodes, No. 4, pp. 3-8. 1980.

[22] S. S. Dada, "Proterozoic Evolution of Nigeria", In: The Basement Complex of Nigeria and its Mineral Resources (Oshin O. ed.), A
Symposium organized to mark the 60th birthday of Prof. M. A. O. Rahaman, held at the Conference Centre, Obafemi Awolowo University, Ile - Ife, Nigeria, May 6th 2006, pp. 29-44.

[23] H. A. Jones and, R. D. Hockey "The Geology of Part of South Western Nigeria", Geol. Surv. Nigeria Bull. No. 31, 101pp. 1964.

[24] M. A. Rahaman, "Recent Advances in the Study of the Basement Complex of Nigeria", Precambrian Geol. Nigeria, Geol. Surv. Nig. Pub., pp. 324-327. 1988.

[25] A.I. Akintola, P.R. Ikhan, O.A. Okunnlola, G.O. Akinttola and O.O. Oyebolu "Compositional features of precambrain pegmatites of Ago-Iwoye area South Western Nigeria. Journal of ecology and natural environment, Vol. 4(3). pp 71/87. 2011.

[26] D. C. Turner, "Upper Proterozoic Schist Belts in the Nigerian Sector of the Pan-African Province of West Africa" Precambr. Res., Vol. 21, pp. $55-79.1983$.

[27] I.Y., Tanko, M. Adam and P.D. Dambring, "Mode of Emplacement of The pegmatites of Keffi Area, North Central Nigeria". International Journal of Scientific 7 Technology Research, Vol. 4, Issue 4. Pp 214-229. 2015.

[28] I. Garba "Geochemical discrimination of Newly Discovered Rare Metal Bearing and Barren Pegmatites in the Pan Afican $600 \pm 150$ Ma Basement of Northern Nigeria", Applied Earth Science Transaction Institute of Mining and Metallurgy, No. 13, Vol. 112, pp. 287-292. 2003.

[29] P. Cerny "Rare-Element Granitc Pegmatites, Part II: Regional to Global Environments and Petrogenesis", Geoscience Can., Vol. 18, pp. 68-81. $1991 \mathrm{~b}$.

[30] R. F. Martin, and C. De Vito, "The Patterns of Enrichment in Felsic Pegmatites Ultimately Depend on Tectonic Setting", Can. Mineral, Vol. 43, pp. 2027-2048. 2005.

[31] D. London "Granitic Pegmatites, an Assessment of Current Concepts and Directions for the Future", Lithos, Vol. 8, pp. 281303., 2005.

[32] K. G.Cox, G. D. Bell, and R. J. Pankhurst, "The Interpretation of Igneous Rocks, George, Allen and Unwen, London. 1979, pp20-36.

[33] J. A., Pearce, N. B. W., Harris, A. G. Tindle, "Trace Element Discrimination Diagram for the Tectonic Interpretation of Granitic Rocks", Journal of Petrology, Vol. 22, pp. 956-983. 1984.

[34] M. A. Peacock, and M. C. Bandy, "Ungemachite and ClinoUngemachite, New Minerals from Chile”, Am. Mineral., Vol. 23, pp. 314-328. 1984. 